Article

\title{
Antioxidant and Anti-Protease Activities of Diazepinomicin from the Sponge-Associated Micromonospora Strain RV115
}

\section{Usama Ramadan Abdelmohsen ${ }^{1, \dagger, *}$, Matthias Szesny ${ }^{2}$, Eman Maher Othman ${ }^{3, \star}$, Tanja Schirmeister ${ }^{4}$, Stephanie Grond ${ }^{2}$, Helga Stopper ${ }^{3}$ and Ute Hentschel ${ }^{1}$}

1 Julius-von-Sachs-Institute for Biological Sciences, University of Würzburg, Julius-von-Sachs-Platz 3, Würzburg 97082, Germany; E-Mail: ute.hentsche1@uni-wuerzburg.de

2 Institute of Organic Chemistry, Eberhard-Karls-Universität, Auf der Morgenstelle 18, Tübingen 72076, Germany; E-Mails: matthias.szesny@uni-tuebingen.de (M.S.); stephanie.grond@uni-tuebingen.de (S.G.)

3 Department of Toxicology, University of Würzburg, Würzburg 97078, Germany; E-Mails: eman@toxi.uni-wuerzburg.de (E.M.O.); stopper@toxi.uni-wuerzburg.de (H.S.)

4 Institute of Pharmacy and Biochemistry, University of Mainz, Staudinger Weg 5, Mainz 55128, Germany; E-Mail: schirmei@uni-mainz.de

$\dagger$ Permanent address: Department of Pharmacognosy, Faculty of Pharmacy, Minia University, Minia 61519, Egypt.

* Permanent address: Department of Analytical Chemistry, Faculty of Pharmacy, Minia University, Minia 61519, Egypt.

* Author to whom correspondence should be addressed; E-Mail: usama.ramadan@uni-wuerzburg.de; Tel.: +49-931-318-0297; Fax: +49-931-888-6235.

Received: 24 July 2012; in revised form: 6 September 2012 / Accepted: 17 September 2012 / Published: 8 October 2012

\begin{abstract}
Diazepinomicin is a dibenzodiazepine alkaloid with an unusual structure among the known microbial metabolites discovered so far. Diazepinomicin was isolated from the marine sponge-associated strain Micromonospora sp. RV115 and was identified by spectroscopic analysis and by comparison to literature data. In addition to its interesting preclinical broad-spectrum antitumor potential, we report here new antioxidant and anti-protease activities for this compound. Using the ferric reducing antioxidant power (FRAP) assay, a strong antioxidant potential of diazepinomicin was demonstrated. Moreover, diazepinomicin showed a significant antioxidant and protective capacity from genomic damage induced by the reactive oxygen species hydrogen peroxide in human
\end{abstract}


kidney (HK-2) and human promyelocytic (HL-60) cell lines. Additionally, diazepinomicin inhibited the proteases rhodesain and cathepsin $\mathrm{L}$ at an $\mathrm{IC}_{50}$ of $70-90 \mu \mathrm{M}$. It also showed antiparasitic activity against trypomastigote forms of Trypanosoma brucei with an $\mathrm{IC}_{50}$ of $13.5 \mu \mathrm{M}$. These results showed unprecedented antioxidant and anti-protease activities of diazepinomicin, thus further highlighting its potential as a future drug candidate.

Keywords: diazepinomicin; anti-protease; antioxidant; actinomycetes; Micromonospora

\section{Introduction}

Diazepinomicin is a farnesylated dibenzodiazepinone that was discovered by Thallion's DECIPHER ${ }^{\circledR}$ platform [1] and was isolated for the first time from the marine Micromonospora strain DPJ12 cultivated from the ascidian Didemnum proliferum at Shishijima Island, Japan [2]. Its biosynthetic pathway was studied by McAlpine [3] and continued by Ratnayake [4]. Diazepinomicin is of considerable interest, owing to its broad-spectrum antitumor activity [5]. It showed a high inhibition potential in cancer cells in vitro, in tumor xenografts in vivo, and a high efficacy in advanced cancer patients, which was confirmed in clinical investigations. This activity is mediated by selective binding to the peripheral benzodiazepine receptor (PBR), resulting in tumor apoptosis and inhibition of the Ras/MAP kinase signaling pathway, which is involved in cellular proliferation and migration [6]. For these reasons, diazepinomicin is currently in phase II clinical trials after having successfully passed phase I clinical trials for Thallion pharmaceuticals.

Free radicals and other reactive oxygen/nitrogen/chlorine species contribute to the development of several age-related diseases and to the aging process itself by causing oxidative stress and oxidative damage $[7,8]$. The implication of oxidative stress in the history of several acute and chronic clinical disorders, such as cancer, atherosclerosis and diabetes, led to the suggestion that antioxidants can be prophylactic agents against such diseases [9-11]. Antioxidant drugs protect from the tissue damage induced by free radicals by preventing their formation, scavenging them, or by promoting their decomposition [12]. Natural products, such as prenylated toluquinones and hydroquinones, were derived from marine sources including sponges, algae and marine microbes, and were found to exhibit good antioxidant properties [13-15].

Proteases are a big family of enzymes that are essential for growth and pathogenicity of bacteria, viruses and parasites. Therefore, they represent new potential targets for anti-infective drugs [16]. Rhodesain is expressed by the parasite Trypanosoma brucei rhodesiense, which is the causative agent of trypanosomiasis. Human cysteine cathepsins were reported to be associated with different mammalian tumors, suggesting their involvement in metastasis, angiogenesis and tumor progression [17]. Several protease inhibitors are in clinical phases for treatment of many diseases such as hypertension, diabetes, infectious diseases and cancer [18,19].

The goal of this study was to obtain deeper insights into the activity profile of diazepinomicin. The antioxidant activity of diazepinomicin was investigated using the chemical ferric reducing antioxidant power (FRAP) method and a cell-based assay in the human promyelocytic cell line HL-60. The cell vitality and protection from oxidative genomic damage was assessed in human kidney HK-2 
cells. Moreover, the effect on the proteases rhodesain and cathepsin L was also examined by enzymatic and HPLC based assays. This work has added new potential insights to the medicinal use of diazepinomicin.

\section{Results and Discussion}

Micromonospora sp. RV115 strain was isolated from the sponge Aplysina aerophoba, which had been collected from Rovinj, Croatia [20]. The strain was fermented in Bennett's medium, and the secondary metabolites were collected via XAD-16 resin, which was then eluted with acetone-methanol. After dissolving the residue in water and extraction with ethyl acetate, the ethyl acetate extract was subjected to normal-phase flash chromatography with cyclohexane:ethyl acetate mixture and to final purification with reversed-phase HPLC using $\mathrm{MeOH}: \mathrm{H}_{2} \mathrm{O}$ mixture supplemented with $0.05 \%$ formic acid to give compound $\mathbf{1}(11.1 \mathrm{mg})$. HR-ESIMS (FTICR) analysis showed that compound $\mathbf{1}$ has an $[\mathrm{M}+\mathrm{H}]^{+}$at 463.2528 and a molecular formula of $\mathrm{C}_{28} \mathrm{H}_{35} \mathrm{~N}_{2} \mathrm{O}_{4}$. A database search using MarinLit database (2012) suggested that this mass coincided with that of diazepinomicin [2]. Analysis of ${ }^{1} \mathrm{H}-\mathrm{NMR}$ data, as well as 2D NMR data, including COSY, HSQC and HMBC spectra, and comparison with those in the literature confirmed the structure of $\mathbf{1}$ as diazepinomicin (Figure 1).

Figure 1. Structure of diazepinomicin (1).

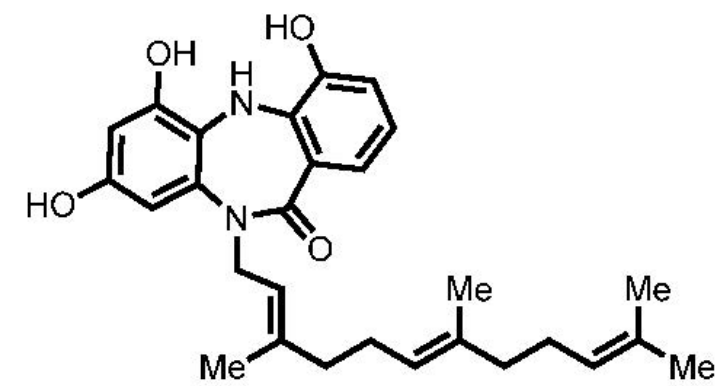

\subsection{Cytotoxicity of Diazepinomicin in Human Kidney Cells (HK-2)}

Because reactive oxygen species (ROS) are an important mediator of renal injury [21,22], diazepinomicin (DZP) cytotoxicity was examined here in the human kidney cell line, HK-2, which was also used by others in oxidative stress studies [21]. HK-2 cells were treated with concentrations of $2-25 \mu \mathrm{M}$ diazepinomicin for $24 \mathrm{~h}$. A small and non-significant $(p>0.05)$ decrease in cell viability of less than $5 \%$ was observed, suggesting that diazepinomicin is not toxic to HK-2 cells.

\subsection{Antioxidant Potential of Diazepinomicin}

The intrinsic antioxidant capacity of diazepinomicin was first assessed using the cell-free system, FRAP (Figure 2). The FRAP assay is based on the measurement of the ability of the substance to reduce $\mathrm{Fe}^{3+}$ to $\mathrm{Fe}^{2+}$, and it directly measures the reducing capacity of the compound, which is considered to be an important parameter for antioxidant function. This method reliably investigates the total antioxidant activity and has been widely used for a rapid assessment of the antioxidant potential of various food, beverages and natural products [23]. Our results demonstrate that diazepinomicin 
exhibited significant antioxidant activity, with $30 \mathrm{nM}$ of diazepinomicin showing an equal potential to $50 \mu \mathrm{M}$ tempol, indicating the strong antioxidant potential of diazepinomicin.

Figure 2. Ferric reducing antioxidant power (FRAP) of cell-free solutions of diazepinomicin assessed by the photometric quantification $(*=$ significant $v s$. control).

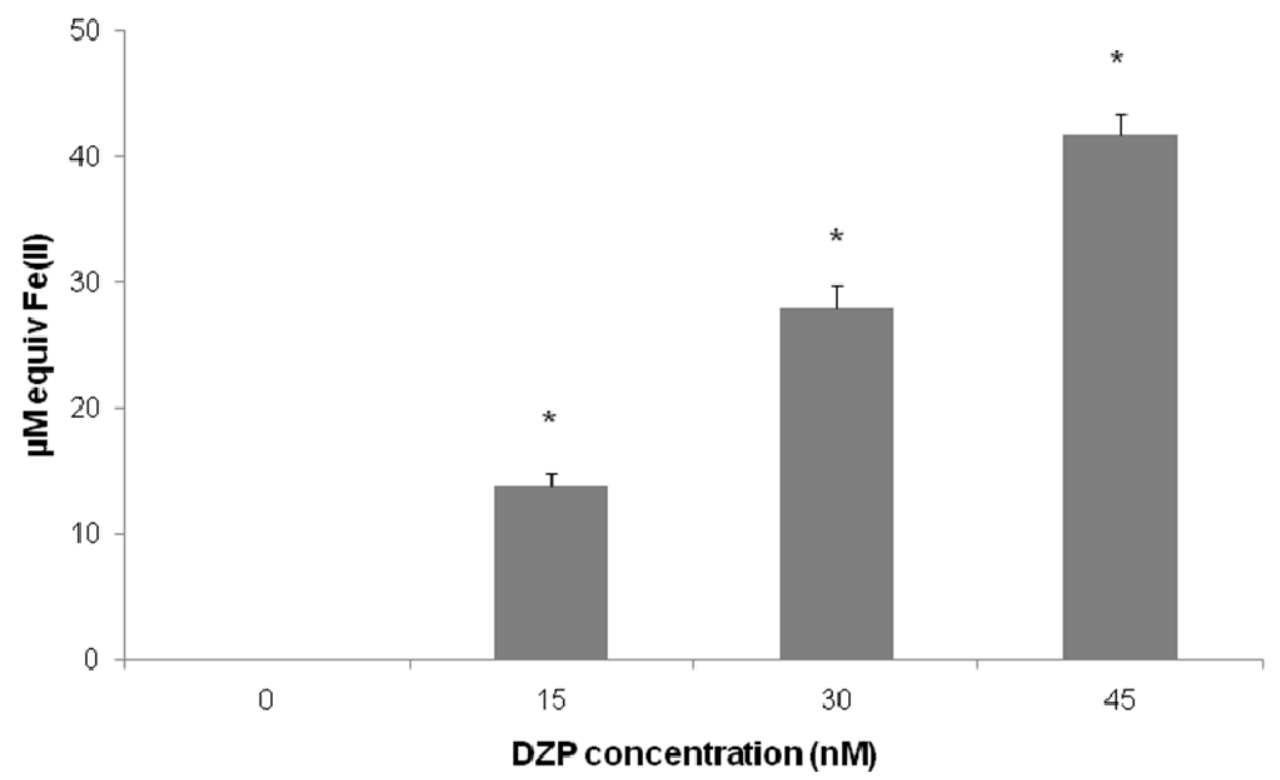

We further examined the antioxidant potential of diazepinomicin in vitro using the dye $2^{\prime}, 7^{\prime}$-dichlorodihydrofluorescein diacetate $\left(\mathrm{H}_{2} \mathrm{DCF}-\mathrm{DA}\right)$. Acetate groups are removed from the molecule by cellular esterases upon entry into live cells, where the dye is oxidized to the fluorescent product dichlorofluorescein (DCF) in the presence of ROS and represents a marker for oxidative stress. The human promyelocytic cell line HL-60 was used here, because of its high sensitivity for oxidative stress. Cells were treated with diazepinomicin $(10,25 \mu \mathrm{M})$ in combination with $50 \mu \mathrm{M} \mathrm{H}_{2} \mathrm{O}_{2}$ as an oxidative stress inducer for $30 \mathrm{~min}$, and the DCF fluorescence was measured using flow cytometric analysis (Figure 3). While diazepinomicin alone did not alter the ROS level in the cells, $\mathrm{H}_{2} \mathrm{O}_{2}$ induced an increase, which was significantly reduced by treatment with $25 \mu \mathrm{M}$ of diazepinomicin. In this test, diazepinomicin was used at higher concentrations to compensate for the artificial oxidative stress effect induced by $50 \mu \mathrm{M} \mathrm{H}_{2} \mathrm{O}_{2}$. These results confirmed the assumption that diazepinomicin has high antioxidant potential. This cell-based assay, in contrast to the cell-free chemical assay FRAP (Figure 2), detects only the antioxidant compounds that can penetrate the cellular membranes of living cells and inhibit the ROS-mediated oxidation intracellularly. Marine natural products, such as aaptamine, isoaaptamine and curcudiol exhibited antioxidant potential in chemical assays but were not able to scavenge free radicals in cell-based assays [24]. This could be explained by the inability to penetrate the cell membrane, or that they are not capable of preventing $2^{\prime}, 7^{\prime}$-dichlorodihydrofluorescein oxidation intracellularly. Our results highlight the antioxidant potential of diazepinomicin by chemical and cell-based assays. 
Figure 3. Flow cytometric analysis for the antioxidant capacity of diazepinomicin in HL-60 cells treated with $50 \mu \mathrm{M} \mathrm{H}_{2} \mathrm{O}_{2}$ and diazepinomicin for $30 \mathrm{~min}(\Delta=$ non significant $v s$. control, $*=$ significant $v s$. control and $\neq=$ significant $v s . \mathrm{H}_{2} \mathrm{O}_{2}$ ).

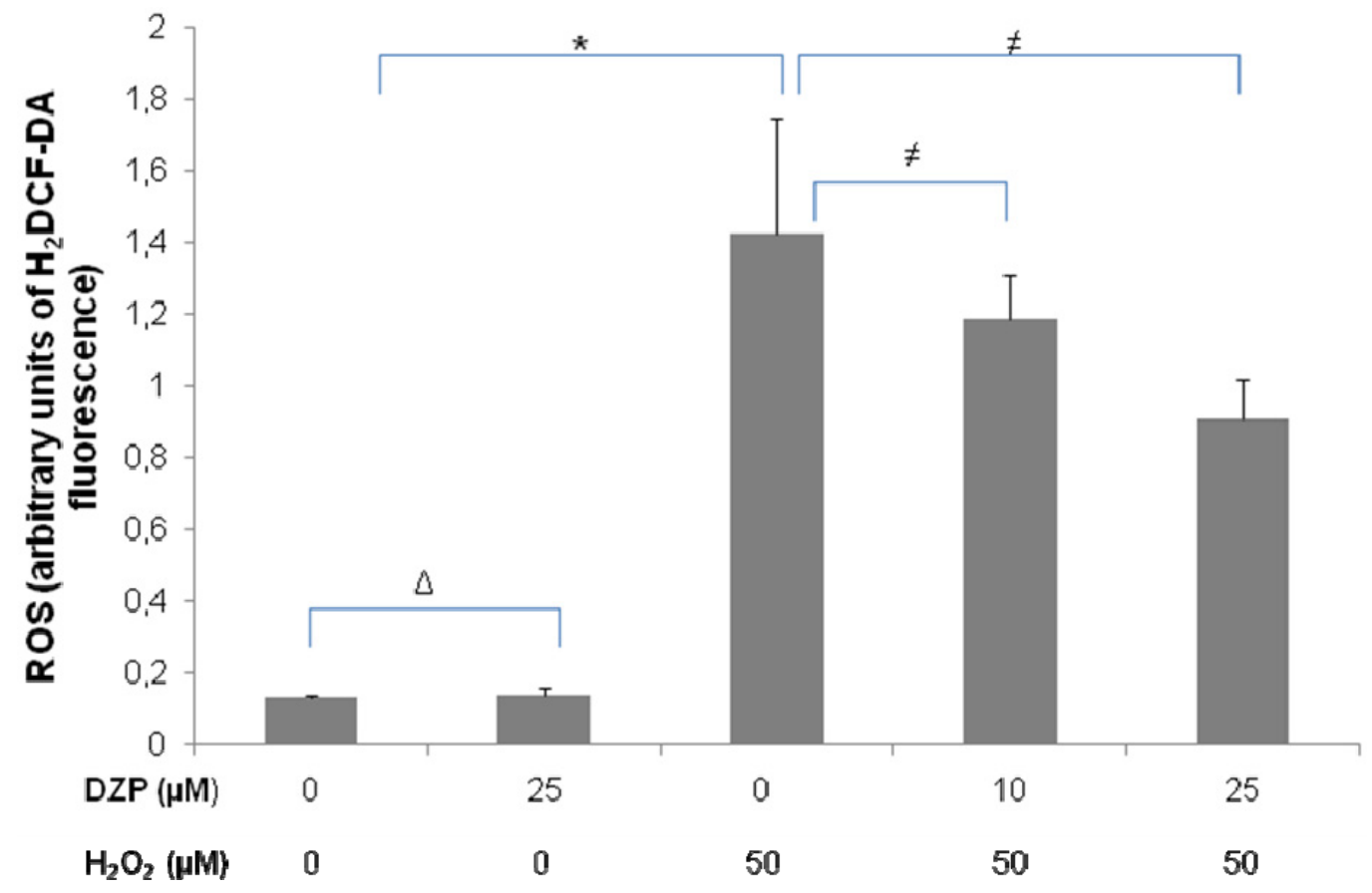

2.3. Protective Effect of Diazepinomicin against Oxidative Stress-Induced Cell Death in HK-2 Cells

Next, we investigated the protective effect of diazepinomicin against oxidative stress-induced cell death using $\mathrm{H}_{2} \mathrm{O}_{2}$. HK-2 cells were treated with $100 \mu \mathrm{M} \mathrm{H}_{2} \mathrm{O}_{2}$ in combination with different concentrations of diazepinomicin for $24 \mathrm{~h}$ (Table 1).

Table 1. Cell death after $24 \mathrm{~h}$ incubation of $\mathrm{HK}-2$ cells with $100 \mu \mathrm{M} \mathrm{H}_{2} \mathrm{O}_{2}$, and different concentrations of diazepinomicin $(2-25 \mu \mathrm{M})$ and $50 \mu \mathrm{M}$ tempol as a positive control for antioxidant activity. $(\Delta=$ non significant increase in cell death, $*=$ significant increase in cell death and $\neq=$ significant decrease in cell death).

\begin{tabular}{l|l}
\hline \multicolumn{1}{c|}{ Test substance } & \multicolumn{1}{|c}{ Cell death (\% dead cells) } \\
\hline Control & $4 \pm 1.0$ \\
$25 \mu \mathrm{M}$ DZP & $4.5 \pm 0.0(\Delta$ vs. control $)$ \\
$50 \mu \mathrm{M}$ tempol & $9.7 \pm 4.3$ \\
$100 \mu \mathrm{M} \mathrm{H}_{2} \mathrm{O}_{2}$ & $21 \pm 5.8(* v s$. control $)$ \\
$100 \mu \mathrm{M} \mathrm{H}_{2} \mathrm{O}_{2}+2 \mu \mathrm{M}$ DZP & $6.5 \pm 4.4\left(\neq v s . \mathrm{H}_{2} \mathrm{O}_{2}\right)$ \\
$100 \mu \mathrm{M} \mathrm{H}_{2} \mathrm{O}_{2}+5 \mu \mathrm{M}$ DZP & $7.5 \pm 1.8\left(\neq v s . \mathrm{H}_{2} \mathrm{O}_{2}\right)$ \\
$100 \mu \mathrm{M} \mathrm{H}_{2} \mathrm{O}_{2}+10 \mu \mathrm{M}$ DZP & $5.3 \pm 1.0\left(\neq v s . \mathrm{H}_{2} \mathrm{O}_{2}\right)$ \\
$100 \mu \mathrm{M} \mathrm{H}_{2} \mathrm{O}_{2}+25 \mu \mathrm{M}$ DZP & $6.3 \pm 2.5\left(\neq v s . \mathrm{H}_{2} \mathrm{O}_{2}\right)$ \\
$100 \mu \mathrm{M} \mathrm{H}_{2} \mathrm{O}_{2}+50 \mu \mathrm{M}$ tempol & $14.7 \pm 5.8$ \\
\hline
\end{tabular}

Our results showed that diazepinomicin (or tempol as a positive control) did not cause significant toxicity, while $\mathrm{H}_{2} \mathrm{O}_{2}$ led to an increased number of dead cells, which was significantly reduced in the 
presence of diazepinomicin. These results indicate that diazepinomicin protected HK-2 cells from $\mathrm{H}_{2} \mathrm{O}_{2}$-induced injury by inhibiting oxidative damage and, ultimately, cell death.

Further investigations included the examination of the protective power of diazepinomicin against oxidative damage of DNA induced by $\mathrm{H}_{2} \mathrm{O}_{2}$ using the alkaline version of the comet assay (Figure 4). This endpoint detects single and double strand breaks, as well as alkali labile sites, on an individual cell basis. For this, HK-2 cells were treated with diazepinomicin or tempol in combination with $100 \mu \mathrm{M}$ $\mathrm{H}_{2} \mathrm{O}_{2}$ for $30 \mathrm{~min}$. While diazepinomicin alone did not cause elevated DNA damage, $\mathrm{H}_{2} \mathrm{O}_{2}$ yielded an increased percentage of DNA in the comet tail, which is the region containing damaged DNA. The $\mathrm{H}_{2} \mathrm{O}_{2}$-induced DNA damage was reduced in a dose-dependent fashion by a combination with tempol or with diazepinomicin.

Figure 4. DNA damage (\% DNA in tail) measured with the comet assay after treatment of HK-2 cells with $100 \mu \mathrm{M} \mathrm{H}_{2} \mathrm{O}_{2}$, and diazepinomicin $(5 \& 15 \mu \mathrm{M})$ and $50 \mu \mathrm{M}$ tempol for $30 \min .(\Delta=$ non significant $v$ s. control, $*=$ significant $v$. control and $\neq=$ significant vs. $\mathrm{H}_{2} \mathrm{O}_{2}$ ).

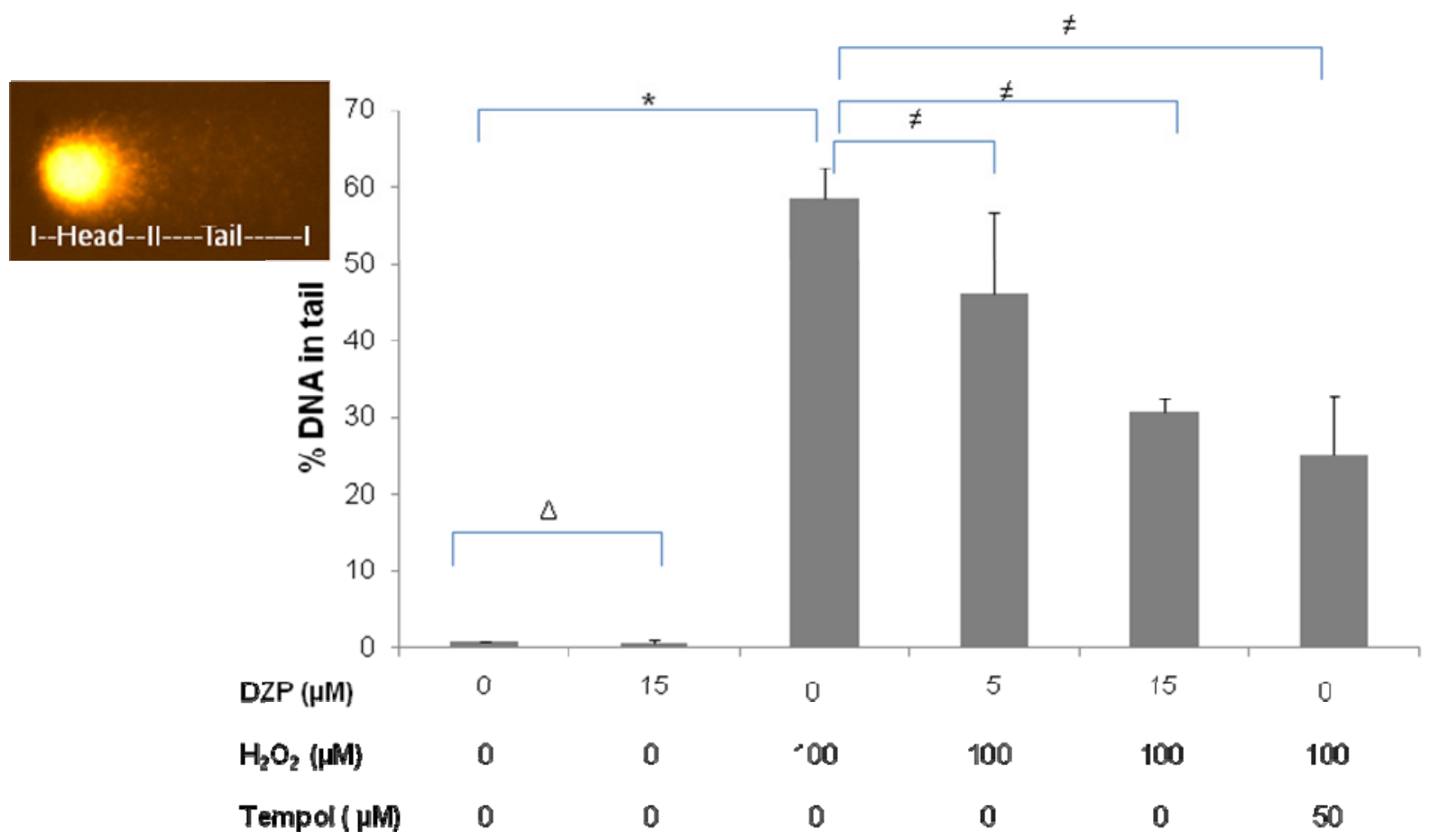

\subsection{Antitrypanosomal and Anti-Protease Activities}

Diazepinomicin was tested for its antitrypanosomal activity against trypomastigote forms of Trypanosoma brucei brucei laboratory strain TC 221 at both 48 and $72 \mathrm{~h}$ time points. Diazepinomicin exhibited $\mathrm{IC}_{50}$ values of 13.57 and $17.06 \mu \mathrm{M}$, respectively, which has not been previously reported in the literature to our knowledge. Since diazepinomicin exhibited activity against Trypanosoma brucei, we tested the compound against the parasite's protease rhodesain. Diazepinomicin showed concentration-dependent inhibition of the hydrolysis of the fluorogenic substrate Cbz-Phe-Arg-AMC (Figure 5). Few natural products with anti-protease activities have been reported from the marine environment. One such example are the new tetromycin derivatives, tetromycins $1-4$, that were 
isolated from Streptomyces axinellae Po1001T, which had been cultivated from the Mediterranean sponge Axinella polypoides. Tetromycins 3-4 exhibited protease inhibition activities against several cysteine proteases [25]. Furthermore, the peptide miraziridine A that was isolated from the marine sponge Theonella swinhoei, exhibited potent activity against cathepsin B [26]. In the present study, the assays with the protease rhodesain at three different substrate concentrations showed diazepinomicin to be a competitive inhibitor with respect to the substrate used (Figure 6). The dissociation constant $K_{\mathrm{i}}$ of inhibition of rhodesain was determined to be $98 \mu \mathrm{M}$.

Figure 5. Progress curves of hydrolysis of the substrate Cbz-Phe-Arg-AMC $(10 \mu \mathrm{M})$ in the absence or presence (from top to bottom) of diazepinomicin ([I] $=0.01-0.02-0.04-0.05$ $-0.06-0.08-0.1 \mathrm{mg} / \mathrm{mL})$.

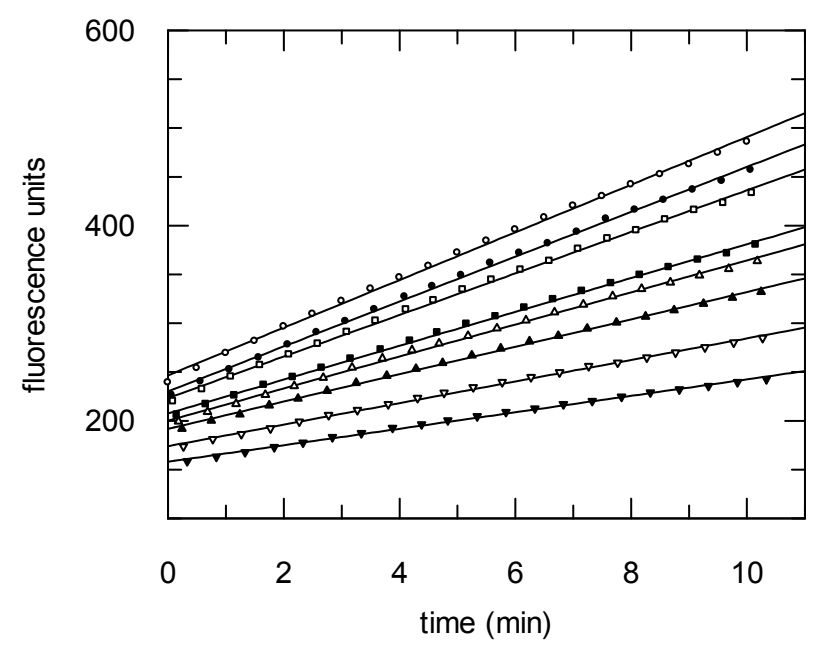

Figure 6. Dependency of $\mathrm{IC}_{50}$ values of the inhibition of rhodesain by diazepinomicin on substrate concentration. Increasing $\mathrm{IC}_{50}$ values at higher substrate concentrations shows diazepinomicin to be a competitive inhibitor. The $K_{\mathrm{i}}$ value (extrapolated $\mathrm{IC}_{50}$ at 0 substrate concentration) was determined to be $0.0456 \mathrm{mg} / \mathrm{mL}(98 \mu \mathrm{M})$.

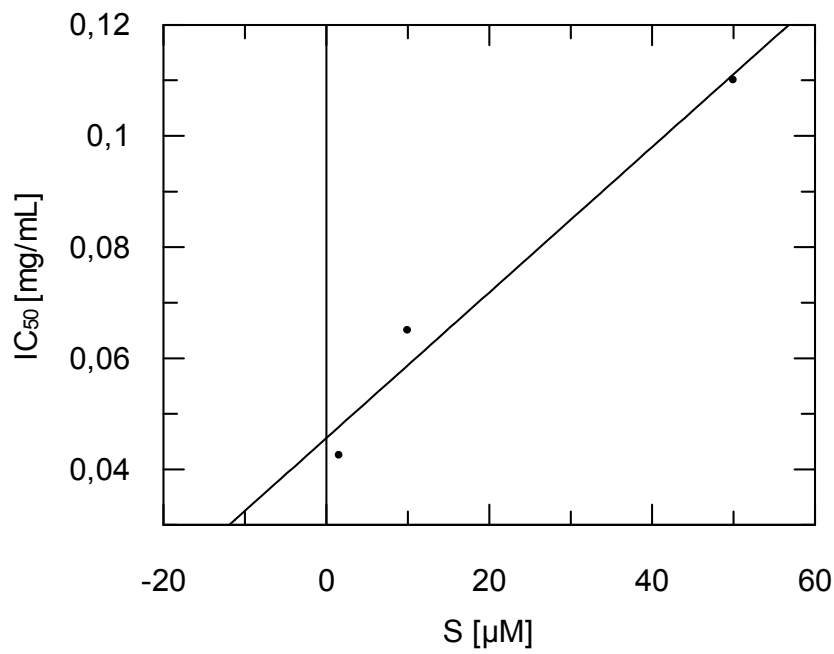

Since rhodesain is a parasite's analog of the human cysteine cathepsins, which are involved in cancer progression and metastasis [27-30], we also tested the activity of diazepinomicin against 
human cathepsin L. Diazepinomicin showed similar activity $\left(\mathrm{IC}_{50}=72.4 \pm 5.3 \mu \mathrm{M}\right.$ at a substrate concentration of $6.25 \mu \mathrm{M}$ from four independent assays). Since diazepinomicin quenches fluorescence of the hydrolysis product AMC (inner filter effect), correction assays were performed according to Ludewig et al. [31]. In order to verify the inhibition, we also detected the substrate hydrolysis by an HPLC-based method. The cathepsin L catalyzed hydrolysis of the substrate (30 min incubation time, $[\mathrm{S}]=6.25 \mu \mathrm{M})$ was quantified in absence and presence of different concentrations of diazepinomicin $(20,100 \mu \mathrm{M})$ after column chromatographic separation of the hydrolysis product and the substrate. These studies proved the inhibitory potency of diazepinomicin $(45 \%$ inhibition at $20 \mu \mathrm{M} ; 64 \%$ at $100 \mu \mathrm{M}$ ). We observed instability of the diazepinomicin DMSO stock solution (stored for more than 4 weeks), which was possibly due to its oxidation. Assays with solutions that were not freshly prepared showed weaker inhibitory activity and $\mathrm{IC}_{50}$ values of $141 \mu \mathrm{M} \pm 20 \mu \mathrm{M}$ (from six independent assays) against cathepsin L. This reduced inhibitory potency with non-freshly prepared stock solutions was also seen in the HPLC-based assays with only $26 \%$ inhibition at $20 \mu \mathrm{M}$, and $36 \%$ inhibition at $80 \mu \mathrm{M}$ diazepinomicin.

In conclusion, diazepinomicin exhibited antioxidant capacity using two different strategies including cell-free and cell-based assays. Diazepinomicin was able to protect cells from toxicity and genomic damage induced by the strong oxidant $\mathrm{H}_{2} \mathrm{O}_{2}$. This antioxidant activity will add a new perspective on the use of diazepinomicin in chemoprevention therapy for different types of cancer. Moreover, diazepinomicin showed anti-protease activity against rhodesain and cathepsin L, which suggests that anti-protease activity may contribute to the anticancer and antitrypanosomal activities as one of the possible mechanism of actions.

\section{Experimental Section}

\subsection{Cultivation and Purification}

Micromonospora sp. RV115 was isolated from the sponge Aplysina aerophoba, which was collected from the Mediterranean Sea [20]. Micromonospora strain RV115 was fermented in $25 \times 1 \mathrm{~L}$ baffled flasks, each containing $200 \mathrm{~mL}$ of Bennett's broth (glucose $10 \mathrm{~g} / \mathrm{L}$, beef extract $0.77 \mathrm{~g} / \mathrm{L}$, yeast extract $1 \mathrm{~g} / \mathrm{L}$, NZ-amine $2 \mathrm{~g} / \mathrm{L}, \mathrm{XAD} 16$ resin $20 \mathrm{~g} / \mathrm{L}$ in 50\% ASW, pH 7.3) at $28{ }^{\circ} \mathrm{C}$ for 9 days with shaking at $180 \mathrm{rpm}$. The harvested culture broth was centrifuged $\left(9000 \mathrm{rpm}, 10 \mathrm{~min}, 2{ }^{\circ} \mathrm{C}\right)$ and the mycelium, together with the XAD 16, were extracted with acetone/methanol $(3 / 7,3 \times 500 \mathrm{~mL})$. The combined extracts were concentrated under vacuum, resuspended in deionized water $(250 \mathrm{~mL})$ and extracted with ethyl acetate $(3 \times 250 \mathrm{~mL}, \mathrm{pH} 5)$. The ethyl acetate extract was purified by normal phase flash chromatography (cyclohexane, ethyl acetate starting with $100 \%$ cyclohexane, 20, 40, 60, 80 up to $100 \%$ ethyl acetate), followed by purification of the fraction with $40 \%$ ethyl acetate with reverse phase HPLC (Nucleodur 100-5 C18 ec), using a gradient 80\%-100\% methanol/water containing $0.05 \%$ formic acid over $20 \mathrm{~min}$ to yield $11.1 \mathrm{mg}$ of diazepinomicin.

\subsection{Ferric Reducing Antioxidant Power (FRAP) Assay}

Total antioxidant activity was measured according to Benzie and Strain [32]. In brief, the FRAP solution was freshly prepared $(25 \mathrm{~mL}$ of $300 \mathrm{mM}$ acetate buffer, $\mathrm{pH} 3.6,2.5 \mathrm{~mL}$ of $20 \mathrm{mM}$ ferric 
chloride hexahydrate dissolved in distilled water, and $2.5 \mathrm{~mL}$ of $10 \mathrm{mM}$ 2,4,6-tripyridyl-s-triazine (TPTZ) dissolved in $40 \mathrm{mM} \mathrm{HCl}) .20 \mu \mathrm{L}$ of diazepinomicin in methanol $(1 \mathrm{mg} / \mathrm{mL})$ was mixed with $600 \mu \mathrm{L}$ of the FRAP solution and $180 \mu \mathrm{L}$ of water. Absorbance was measured at $595 \mathrm{~nm}$ after 6 min of incubation at room temperature by a spectrophotometer (Bio-Tek, Model Uvikon XL) against a blank of distilled water. Tempol was tested at the final concentration of $50 \mu \mathrm{M}$ and used as the reference compound. FRAP values were obtained by comparing the absorbance change at $595 \mathrm{~nm}$ in test reaction mixtures with those containing ferrous ions in known concentrations. Absorbance changes are linear over a wide concentration range with antioxidant mixtures.

\subsection{Cell Culture Maintenance}

HK-2, a human kidney cell line with many properties of proximal tubular cells, was obtained from Dr. G. Garibotto, Department of Internal Medicine and Urology, University of Genoa, Italy. Cells were cultured two times per week at $37{ }^{\circ} \mathrm{C}$ in DMEM/F12 medium (PAA Laboratories GmbH, Pasching, Austria) supplemented with $5 \%$ fetal calf serum, $2 \mathrm{mM}$ of L-glutamine, $1 \%$ antibiotics $(50 \mathrm{U} / \mathrm{mL}$ penicillin, $50 \mathrm{mg} / \mathrm{mL}$ streptomycin), $10 \mu \mathrm{g} / \mathrm{L}$ epidermal growth factor, $5 \mu \mathrm{g} / \mathrm{L}$ hydrocortisone, $5 \mu \mathrm{g} / \mathrm{L}$ sodium selenate, $5 \mathrm{ng} / \mathrm{L}$ bovine pituitary extract, $5 \mathrm{mg} / \mathrm{L}$ transferrin, and $5 \mathrm{mg} / \mathrm{L}$ insulin and $5 \mathrm{ng} / \mathrm{L}$ T3.

HL-60, a human promyelocytic cell line was donated by Prof. R. Schinzel, Vasopharm GmbH, Würzburg, Germany. HL-60 cells were cultured three times per week at $37{ }^{\circ} \mathrm{C}, 5 \%$ (v/v) $\mathrm{CO}_{2}$ in $\mathrm{RPMI}$ 1640 medium, supplemented with 10\% (v/v) fetal bovine serum (FBS), 1\% (w/v) L-glutamine and $0.4 \%(\mathrm{w} / \mathrm{v})$ antibiotics $(50 \mathrm{U} / \mathrm{mL}$ penicillin, and $50 \mathrm{mg} / \mathrm{mL}$ streptomycin).

\subsection{Flow Cytometric Quantification of Antioxidant Activity}

The potential of antioxidant activity was estimated using the probe $2^{\prime}, 7^{\prime}$-dichlorodihydrofluorescein diacetate $\left(\mathrm{H}_{2}\right.$ DCF-DA). The cell-permeable $\mathrm{H}_{2}$ DCF-DA is non-fluorescent until the acetate groups are removed by intracellular esterases and until oxidation occurs within the cell, leading to the fluorescent product dichlorofluorescein (DCF). Oxidation of this probe can be detected by monitoring the increase in fluorescence using flow cytometer with filters appropriate for fluorescein (FITC). HL-60 cells $\left(5 \times 10^{5}\right)$ were seeded in $25 \mathrm{~cm}^{2}$ flasks and incubated in medium containing $50 \mu \mathrm{M} \mathrm{H}_{2} \mathrm{O}_{2}, 25 \mu \mathrm{M}$ diazepinomicin or $\mathrm{H}_{2} \mathrm{O}_{2}$ with diazepinomicin $(10$ and $25 \mu \mathrm{M})$ for $30 \mathrm{~min}$. At the last $10 \mathrm{~min}$ of the treatment, $10 \mu \mathrm{M} \mathrm{H} \mathrm{H}_{2}$ DCF-DA were additionally loaded. Afterwards, the medium was removed, the cells were rinsed with PBS, and $1 \mathrm{~mL}$ of BSA/PBS was added per flask. Fluorescence was measured at $\lambda_{\text {exc }} 475 \mathrm{~nm} ; \lambda_{\text {em }} 525 \mathrm{~nm}$. To determine the viability of the cells during the process, samples were subsequently incubated with $0.1 \%$ (v/v) $50 \mu \mathrm{M}$ PI, incubated for $10 \mathrm{~min}$ at room temperature, and the fluorescence $\left(\lambda_{\text {exc }} 538 \mathrm{~nm}, \lambda_{\text {em }} 590 \mathrm{~nm}\right.$ ) was measured. Results are expressed as the ratio DCF (dichlorofluorescein) fluorescence/PI fluorescence.

\subsection{Vitality Test}

The assay was performed as described by Schmitt et al. [33]. However, ethidium bromide was replaced with Gel RedBiotrend (Köln, Germany). Vitality staining was performed for the HK-2 cells treated with different concentrations of diazepinomicin $(2$ to $25 \mu \mathrm{M})$ for 24 h. $0.35 \times 10^{6}$ cells were 
seeded in $25 \mathrm{~cm}^{2}$ flasks for $24 \mathrm{~h}$ in a control medium. After treatment with diazepinomicin or tempol as positive control, cells were harvested, and $70 \mu \mathrm{L}$ of the cell suspension was stained with $30 \mu \mathrm{L}$ staining solution. Twenty microliter of this mixture was applied to the slide, and the fractions of green and red cells in a total of 200 cells were counted at a 500-fold magnification with a fluorescence microscope.

\subsection{Comet Assay}

After treatment of HK-2 cells with $100 \mu \mathrm{M} \mathrm{H}_{2} \mathrm{O}_{2}$ alone, or with $\mathrm{H}_{2} \mathrm{O}_{2}$ and diazepinomicin (5 and $15 \mu \mathrm{M})$, the cells were harvested, and $20 \mu \mathrm{L}$ of the treated cell suspension were mixed with $180 \mu \mathrm{L}$ of $0.5 \%$ low melting agarose and added to fully frosted slides that had been covered with a bottom layer of $1 \%$ normal melting point agarose. The slides were incubated in lysis solution $(2.5 \mathrm{M} \mathrm{NaCl}, 0.1 \mathrm{M}$ EDTA, $0.01 \mathrm{M}$ Tris and 1\% Triton X-100, $10 \mathrm{~g} / \mathrm{L} N$-lauroylsarcosine sodium adjusted to $\mathrm{pH} 10$ with $\mathrm{NaOH})$ at $4{ }^{\circ} \mathrm{C}$. After $1 \mathrm{~h}$, the slides were washed and then placed in the electrophoresis solution (300 $\mathrm{mM}$ $\mathrm{NaOH}, 1 \mathrm{mM}$ EDTA, $\mathrm{pH}>13.0$ ) for $20 \mathrm{~min}$. The electrophoresis was conducted for $20 \mathrm{~min}$ at $25 \mathrm{~V}$ $(1.1 \mathrm{~V} / \mathrm{cm})$ and $300 \mathrm{~mA}$. The slides were neutralized in $0.4 \mathrm{M}$ Tris buffer $(\mathrm{pH} 7.5)$ and then dehydrated in methanol for $10 \mathrm{~min}$ at $-20^{\circ} \mathrm{C}$. The slides were left at $37^{\circ} \mathrm{C}$ in an incubator to dry and then stored at room temperature. Before evaluation, $20 \mu \mathrm{L}$ of Gel red /DABCO solution was added to each slide. Images of 50 randomly selected cells ( 25 per replicate slide) for each sample were analyzed with a fluorescence microscope (Labophot 2, Nikon, Germany) at 200-fold magnification using image analysis software (Komet 5, BFI Optilas, Germany). A representative picture of a damaged cell in the comet assay is inserted into Figure 4. While intact nuclear DNA remains in the head region of the cellular comet, damaged DNA moves faster during electrophoresis and, thus, forms the tail region of the cellular comet. The percentage of DNA in the tail region was used to quantify DNA damage-related migration.

\subsection{Statistics for Cell Based Assays}

Data from 3 independent experiments \pm standard deviation are depicted. Statistical significance among multiple groups was tested with the Kruskal-Wallis test. Individual groups were then tested using the Mann Whitney U-test, and results were considered significant if the $p$-value was $\leq 0.05$.

\subsection{Antitrypanosomal Activity}

Antitrypanosomal assay was done as described by Huber and Koella [34]. In brief, trypomastigote forms of Trypanosoma brucei brucei laboratory strain TC 221 were cultured in Complete Baltz medium [35], and a defined number of parasites $\left(10^{4}\right.$ trypanosomes per $\left.\mathrm{mL}\right)$ were exposed in test chambers of 96-well plates to various concentrations of diazepinomicin (previously dissolved in DMSO) to make a final volume of $200 \mu \mathrm{L}$ in duplicates. Trypanosomes in a culture medium as a positive control, and diazepinomicin without trypanosomes as a negative control were run simultaneously with each plate. After incubating the plates at $37{ }^{\circ} \mathrm{C}$ in an atmosphere of $5 \% \mathrm{CO}_{2}$ for a total time period of $72 \mathrm{~h}, 20 \mu \mathrm{L}$ of Alamar Blue was added and the activity was measured by light absorption using Microplate Reader MR 700 at a wavelength of $550 \mathrm{~nm}$ with a reference wave length 
of $630 \mathrm{~nm}$. First reading was done at $48 \mathrm{~h}$ and subsequently at $72 \mathrm{~h}$. The effect of the test substances was quantified in $\mathrm{IC}_{50}$ values by linear interpolation of three independent measurements.

\subsection{Protease Assays}

The assays were performed as previously described [36]. In brief, the hydrolysis of Cbz-Phe-Arg-AMC by either rhodesain or human cathepsin $\mathrm{L}$ was detected continuously over a period of 10 min using a Varian Cary Eclipse spectrofluorometer (Varian, Darmstadt, Germany) with a microplate reader (excitation at $365 \mathrm{~nm}$, emission at $460 \mathrm{~nm}, 25^{\circ} \mathrm{C}$ ). The following buffer solutions were used: $50 \mathrm{mM}$ sodium acetate buffer, $\mathrm{pH} 5.5$ containing $2 \mathrm{mM}$ (cathepsin L), or $5 \mathrm{mM}$ (rhodesain) DTT, $5 \mathrm{mM}$ EDTA, $200 \mathrm{mM} \mathrm{NaCl}$ and $0.005 \%$ Brij 35. DMSO stock solutions of substrate and inhibitor were freshly prepared. DMSO alone (7.5\% final concentration) was used as a negative control.

For the HPLC based assay, the same conditions were used: the enzymatic hydrolysis of the substrate in absence or presence of diazepinomicin was stopped after $30 \mathrm{~min}$ by diluting the reaction with acetonitrile. The reaction mixtures $(50 \mu \mathrm{L})$ were submitted to HPLC, and the amounts of AMC produced and of residual substrate Cbz-Phe-Arg-AMC were detected after separation using a Waters symmetry C18 column $(3.5 \mu \mathrm{m}, 4.6 \times 75 \mathrm{~mm})$ and a gradient with the solvents, A: phosphate buffer $25 \mathrm{mM}$ pH 6.0 with 10\% methanol; and B: methanol (from $10 \% \mathrm{~A} / 90 \% \mathrm{~B}$ to $100 \% \mathrm{~A} / 0 \% \mathrm{~B}$ within $40 \mathrm{~min}$, flow $0.8 \mathrm{~mL} / \mathrm{min}$ ). A diode array detector (DAD) was used (210-400 nm). The AMC peak (retention time $2 \mathrm{~min}$ ) was quantified (area under the curve, AUC) at $347 \mathrm{~nm}$, whereas the substrate peak (retention time $30 \mathrm{~min}$ ) was quantified at $326 \mathrm{~nm}$. The percentage of inhibition by diazepinomicin was calculated for each experiment comparing the AUCs of the substrate peaks without enzyme, after $30 \mathrm{~min}$ incubation of substrate and enzyme, after $30 \mathrm{~min}$ incubation of substrate, enzyme and inhibitor, and by comparing the AUCs of the AMC peaks after 30 min incubation of substrate and enzyme with those obtained after 30 min incubation of substrate, enzyme and inhibitor. Each experiment was performed in triplicate.

\section{Conclusions}

Our results showed that diazepinomicin exhibited antioxidant capacity using two different strategies including cell-free and cell-based assays. Diazepinomicin was able to protect cells from toxicity and genomic damage induced by the strong oxidant $\mathrm{H}_{2} \mathrm{O}_{2}$. This antioxidant activity will add a new perspective on the use of diazepinomicin in chemoprevention therapy for different types of cancer. Moreover, diazepinomicin showed anti-protease activity against rhodesain and cathepsin L, which suggests that anti-protease activity may contribute to the anticancer and antitrypanosomal activities as one of the possible mechanism of actions.

\section{Acknowledgments}

We gratefully acknowledge Swarna Oli for her help in the anti-protease assays and Eylül Bankoglu for her assistance in the antioxidant assays (University of Würzburg). Financial support was provided by DFG SFB 630 TP A5 to U. H and TP A4 to T. S. This publication was funded by the German Research Foundation (DFG) and the University of Wuerzburg in the funding programme Open Access Publishing. 


\section{References}

1. Zazopoulos, E.; Huang, K.; Staffa, A.; Liu, W.; Bachmann, B.O.; Nonaka, K.; Ahlert, J.; Thorson, J.S.; Shen, B.; Farnet, C.M. A genomics-guided approach for discovering and expressing cryptic metabolic pathways. Nat. Biotechnol. 2003, 21, 187-190.

2. Charan, R.D.; Schlingmann, G.; Janso, J.; Bernan, V.; Feng, X.; Carter, G.T. Diazepinomicin, a new antimicrobial alkaloid from a marine Micromonospora sp. J. Nat. Prod. 2004, 67, 1431-1433.

3. McAlpine, J.B.; Banskota, A.H.; Charan, R.D.; Schlingmann, G.; Zazopoulos, E.; Piraee, M.; Janso, J.; Bernan, V.S.; Aouidate, M.; Farnet, C.M.; et al. Biosynthesis of diazepinomicin/ ECO-4601, a Micromonospora secondary metabolite with a novel ring system. J. Nat. Prod. 2008, $71,1585-1590$.

4. Ratnayake, A.S.; Janso, J.E.; Feng, X.; Schlingmann, G.; Goljer, I.; Carter, G.T. Evaluating indole-related derivatives as precursors in the directed biosynthesis of diazepinomicin analogues. J. Nat. Prod. 2009, 72, 496-499.

5. Campas, C. Diazepinomicin. Drug Fut. 2009, 34, 349-351.

6. Wong, K.K. Recent developments in anti-cancer agents targeting the Ras/Raf/ MEK/ERK pathway. Recent Pat. Anticancer Drug Discov. 2009, 4, 28-35.

7. Halliwell, B.; Gutteridge, J. Free Radicals in Biology and Medicine; Clarendon Press: New York, NY, USA, 1999; pp. 20-37.

8. Sohal, R.S.; Mockett, R.J.; Orr, W.C. Mechanisms of aging: an appraisal of the oxidative stress hypothesis. Free Radic. Biol. Med. 2002, 33, 575-586.

9. Chowienczyk, P.J.; Brett, S.E.; Gopaul, N.K.; Meeking, D.; Marchetti, M.; Russell-Jones, D.L.; Anggard, E.E.; Ritter, J.M. Oral treatment with an antioxidant (raxofelast) reduces oxidative stress and improves endothelial function in men with type II diabetes. Diabetologia 2000, 43, 974-977.

10. Parthasarathy, S.; Santanam, N.; Ramachandran, S.; Meilhac, O. Potential role of oxidized lipids and lipoproteins in antioxidant defense. Free Radic. Res. 2000, 33, 197-215.

11. DeNicola, G.M.; Karreth, F.A.; Humpton, T.J.; Gopinathan, A.; Wei, C.; Frese, K.; Mangal, D.; $\mathrm{Yu}$, K.H.; Yeo, C.J.; Calhoun, E.S.; et al. Oncogene-induced Nrf2 transcription promotes ROS detoxification and tumorigenesis. Nature 2011, 475, 106-109.

12. Young, I.S.; Woodside, J.V. Antioxidants in health and disease. J. Clin. Pathol. 2001, 54, 176-186.

13. Zhang, C.Y.; Wu, W.H.; Wang, J.; Lan, M.B. Antioxidant properties of polysaccharide from the brown seaweed Sargassum graminifolium (Turn.), and its effects on calcium oxalate crystallization. Mar. Drugs 2012, 10, 119-130.

14. Song, L.; Li, T.; Yu, R.; Yan, C.; Ren, S.; Zhao, Y. Antioxidant activities of hydrolysates of Arca subcrenata prepared with three proteases. Mar. Drugs 2008, 6, 607-619.

15. Sunassee, S.N.; Davies-Coleman, M.T. Cytotoxic and antioxidant marine prenylated quinones and hydroquinones. Nat. Prod. Rep. 2012, 29, 513-535.

16. Zhang, C.; Kim, S.K. Matrix metalloproteinase inhibitors (MMPIs) from marine natural products: The current situation and future prospects. Mar. Drugs 2009, 7, 71-84. 
17. Hsieh, C.C.; Hernandez-Ledesma, B.; Jeong, H.J.; Park, J.H.; de Lumen, B.O. Complementary roles in cancer prevention: Protease inhibitor makes the cancer preventive peptide lunasin bioavailable. PLoS One 2010, 5, e8890.

18. Cai, H.; Kuang, R.; Gu, J.; Wang, Y. Proteases in malaria parasites - a phylogenomic perspective. Curr. Genomics 2011, 12, 417-427.

19. McKerrow, J.H.; Rosenthal, P.J.; Swenerton, R.; Doyle, P. Development of protease inhibitors for protozoan infections. Curr. Opin. Infect. Dis. 2008, 21, 668-672.

20. Abdelmohsen, U.R.; Pimentel-Elardo, S.M.; Hanora, A.; Radwan, M.; Abou-El-Ela, S.H.; Ahmed, S.; Hentschel, U. Isolation, phylogenetic analysis and anti-infective activity screening of marine sponge-associated actinomycetes. Mar. Drugs 2010, 8, 399-412.

21. Verzola, D.; Bertolotto, M.B.; Villaggio, B.; Ottonello, L.; Dallegri, F.; Salvatore, F.; Berruti, V.; Gandolfo, M.T.; Garibotto, G.; Deferrari, G. Oxidative stress mediates apoptotic changes induced by hyperglycemia in human tubular kidney cells. J. Am. Soc. Nephrol. 2004, 15 (Suppl. 1), S85-S87.

22. Djamali, A. Oxidative stress as a common pathway to chronic tubulointerstitial injury in kidney allografts. Am. J. Physiol. Renal Physiol. 2007, 293, F445-F455.

23. Moyer, R.A.; Hummer, K.E.; Finn, C.E.; Frei, B.; Wrolstad, R.E. Anthocyanins, phenolics, and antioxidant capacity in diverse small fruits: Vaccinium, rubus, and ribes. J. Agric. Food Chem. 2002, 50, 519-525.

24. Takamatsu, S.; Hodges, T.W.; Rajbhandari, I.; Gerwick, W.H.; Hamann, M.T.; Nagle, D.G. Marine natural products as novel antioxidant prototypes. J. Nat. Prod. 2003, 66, 605-608.

25. Pimentel-Elardo, S.M.; Buback, V.; Gulder, T.A.; Bugni, T.S.; Reppart, J.; Bringmann, G.; Ireland, C.M.; Schirmeister, T.; Hentschel, U. New tetromycin derivatives with anti-trypanosomal and protease inhibitory activities. Mar. Drugs 2011, 9, 1682-1697.

26. Tabares, P.; Degel, B.; Schaschke, N.; Hentschel, U.; Schirmeister, T. Identification of the protease inhibitor miraziridine A in the Red sea sponge Theonella swinhoei. Pharmacogn. Res. 2012, 4, 63-66.

27. Leto, G.; Sepporta, M.V.; Crescimanno, M.; Flandina, C.; Tumminello, F.M. Cathepsin L in metastatic bone disease: therapeutic implications. Biol. Chem. 2010, 391, 655-664.

28. Yan, J.A.; Xiao, H.; Ji, H.X.; Shen, W.H.; Zhou, Z.S.; Song, B.; Chen, Z.W.; Li, W.B. Cathepsin L is associated with proliferation and clinical outcome of urothelial carcinoma of the bladder. J. Int. Med. Res. 2010, 38, 1913-1922.

29. Colella, R.; Lu, G.; Glazewski, L.; Korant, B.; Matlapudi, A.; England, M.R.; Craft, C.; Frantz, C.N.; Mason, R.W. Induction of cell death in neuroblastoma by inhibition of cathepsins B and L. Cancer Lett. 2010, 294, 195-203.

30. Joyce, J.A.; Baruch, A.; Chehade, K.; Meyer-Morse, N.; Giraudo, E.; Tsai, F.Y.; Greenbaum, D.C.; Hager, J.H.; Bogyo, M.; Hanahan, D. Cathepsin cysteine proteases are effectors of invasive growth and angiogenesis during multistage tumorigenesis. Cancer Cell 2004, 5, 443-453.

31. Ludewig, S.; Kossner, M.; Schiller, M.; Baumann, K.; Schirmeister, T. Enzyme kinetics and hit validation in fluorimetric protease assays. Curr. Top. Med. Chem. 2010, 10, 368-382.

32. Benzie, I.F.; Strain, J.J. Ferric reducing/antioxidant power assay: direct measure of total antioxidant activity of biological fluids and modified version for simultaneous measurement of total antioxidant power and ascorbic acid concentration. Methods Enzymol. 1999, 299, 15-27. 
33. Schmitt, E.; Lehmann, L.; Metzler, M.; Stopper, H. Hormonal and genotoxic activity of resveratrol. Toxicol. Lett. 2002, 136, 133-142.

34. Huber, W.; Koella, J.C. A comparison of three methods of estimating $\mathrm{EC}_{50}$ in studies of drug resistance of malaria parasites. Acta Trop. 1993, 55, 257-261.

35. Baltz, T.; Baltz, D.; Giroud, C.; Crockett, J. Cultivation in a semi-defined medium of animal infective forms of Trypanosoma brucei, T. equiperdum, T. evansi, T. rhodesiense and T. gambiense. EMBO J. 1985, 4, 1273-1277.

36. Breuning, A.; Degel, B.; Schulz, F.; Buchold, C.; Stempka, M.; Machon, U.; Heppner, S.; Gelhaus, C.; Leippe, M.; Leyh, M.; et al. Michael acceptor based antiplasmodial and antitrypanosomal cysteine protease inhibitors with unusual amino acids. J. Med. Chem. 2010, $53,1951-1963$.

Samples Availability: Available from the authors.

(C) 2012 by the authors; licensee MDPI, Basel, Switzerland. This article is an open access article distributed under the terms and conditions of the Creative Commons Attribution license (http://creativecommons.org/licenses/by/3.0/). 